\title{
SURVEI TERHADAP PENGGUNAAN NAMA YESUS DALAM TEKS- TEKS TERKAIT PENGUSIRAN SETAN DI PERJANJIAN BARU
}

\author{
Abel Kristofel Aruan \\ Sekolah Tinggi Teologi Seminari Alkitab Asia Tenggara \\ Jalan Bukit Hermon no. 1, Tidar Atas, Malang, Jawa Timur 65151 \\ Email: abelkristofel.saat@gmail.com
}

\begin{abstract}
ABSTRAK: Artikel ini ditulis berdasarkan sebuah dugaan bahwa ada praktik-praktik pengusiran setan yang menggunakan penyebutan nama Yesus atau frasa "dalam/demi nama Yesus" dalam proses ritualnya. Survey dilakukan terhadap ayat-ayat di Perjanjian Baru yang terkait dengan preskripsi maupun kisah-kisah pengusiran setan. Melalui metode penelitian literatur (kepustakaan), artikel ini mencoba mempertanyakan apakah praktik pengusiran setan mengharuskan seseorang untuk mengucapkan nama Yesus sebagai syarat agar ritual berhasil atau tidak. Tulisan ini akan menggolongkan ayat-ayat ke dalam tiga kategori: (1) ayat-ayat terkait pengusiran setan yang tidak mengandung pengucapan nama Yesus (Mat. 8:16; 9:34; 12:24, 27-28; 17:19; Mrk. 1:34); (2) ayat-ayat narasi pengusiran setan yang memunculkan frasa "dalam/demi nama Yesus" dalam narasinya (Mat. 7:22; Mrk. 16:17; Mrk 9:38; Luk. 9:49); dan (3) ayat-ayat narasi pengusiran setan yang tokohnya mengucapkan "dalam/demi nama Yesus" secara verbal (Kis. 16:18; 19:13). Melalui penelusuran sejauh ini, artikel ini menyimpulkan bahwa teks-teks Perjanjian Baru tidak mengharuskan seseorang untuk mengucapkan nama Yesus ketika mengusir setan. Apa yang paling penting dalam proses pengusiran setan adalah relasi antara pengusir setan dengan Yesus serta keyakinan terhadap kuasa pengusiran setan yang diberikan oleh Yesus.
\end{abstract}

Kata Kunci: pengusiran setan, paulus, kisah para rasul, perjanjian baru, demonologi, anneliese michel, katekismus gereja katholik.

\section{A SURVEY ON THE USE OF JESUS' NAME IN THE TEXTS RELATED TO EXORCISM IN NEW TESTAMENT}

\begin{abstract}
This writing is based on a notion that there are practices of exorcism that contain the spelling of Jesus' name or phrase "by/in the name of Jesus" in the ritual process. This article surveyed the New Testament texts related to exorcism prescriptions or narratives. Through the method of literary research, this article tries to question whether the practice of exorcism necessitates one to spell Jesus' name as a requirement to make the ritual succeed or not. This writing will classify biblical account into three groups: (1) the verses on exorcism that do not contain spelling Jesus' name (Matt. 8:16; 9:34; 12:24, 27-28; 17:19; Mark 1:34); (2) the narratives account on exorcism which contain phrase "in/by the name of Jesus" on its narratives; and (3) the narratives account in which its character spells orally "in/by the name of Jesus" (Acts 16:18; 19:13). As the result, the article concludes that the NT texts do not necessitate someone to spell Jesus' name during the exorcism. The most important element in exorcism is the relationship between the exorcist and Jesus himself and faith in the power to cast the demons out, which is given by Jesus.
\end{abstract}

Keywords: exorcism, apostle paul, acts, new testament, demonology, anneliese michel, cathecism of catholic church 


\section{PENDAHULUAN}

Anneliese Michel, seorang pemudi Katolik berusia 17 tahun, diberitakan mengalami kerasukan beberapa roh yang terindikasi sebagai Lucifer, Yudas Iskariot, Nero, Kain dan Adolf Hitler. Pada tahun 1973 dia mengalami banyak gejala-gejala aneh yang membuat orang tuanya harus meminta ritual pengusiran setan (exorcism). Tahun 1975 dia meminta ritual dilakukan lagi oleh karena gejala tidak mereda. Setahun berikutnya dia meninggal dunia karena kelaparan. Itu adalah jalur penyiksaan diri yang dia pilih sendiri untuk membebaskan dirinya dari cengkraman setan (Wolff, 2006; Ney-Hellmuth, 2014). Kisah Michel inilah yang akhirnya menginspirasi pembuatan film The Exorcism of Emily Rose (2005) (May, 2014). ${ }^{1}$

Dalam prosesnya pastor berusaha menunjukkan otoritas dan superioritasnya di hadapan setan yang membelenggu Michel. Keberanian dan kemauan bertindak dalam melawan kuasa setan ini jelas hanya bisa dimiliki bila seseorang yang yakin bahwa Yesus Kristus memberikan otoritas padanya. Situs Catholic.org menampilkan ritual pengusiran setan yang kemungkinan besar jadi panduan banyak klergi di seluruh dunia. Dalam situs itu diperlihatkan adanya "peminjaman otoritas" yang dilakukan oleh pelaku pengusiran setan.

Dalam panduan tersebut, imam yang diutus gereja terlebih dahulu harus sujud melakukan Litany of the Saints. Dia, dan seluruh petinggi gereja, harus meminta belas kasihan dari Tuhan agar dilayakkan untuk mengusir setan. Litany of the Saints ditutup dengan Doa Bapa Kami yang berhenti pada kalimat, "But deliver us from evil."

Setelah ritual tersebut dilakukan, imam akan memulai pengusiran setan (Your Catholic Voice Foundation, 2017). ${ }^{2}$ Imam harus memerintahkan setan dengan pernyataan,

I command you, unclean spirit, whoever you are, along with all your minions now attacking this servant of God, by the mysteries of the incarnation, passion, resurrection, and ascension of our Lord Jesus Christ, by the descent of the Holy Spirit, by the coming of our Lord for judgment, that you tell me by some sign your name, and the day and hour of your departure. I command you, moreover, to obey me to the letter, I who am a minister of God despite my unworthiness; nor shall you be emboldened to harm in any way this creature of God, or the bystanders, or any of their possessions (Your Catholic Voice Foundation, 2017).

Tampak bahwa doa tersebut mengindikasikan pelibatan Kristus dalam proses pengusiran setan.

Selanjutnya, imam akan mengarahkan salib pada penderita dan mulai mengucapkan pernyataan hardikan yang makin menunjukkan peminjaman otoritas Kristus. Kalimat itu berbunyi demikian:

I cast you out, unclean spirit, along with every Satanic power of the enemy, every spectre from hell, and all your fell companions; in the name of our Lord Jesus +Christ. Begone and stay far from this creature of God. +For it is He who commands you, $\mathrm{He}$ who flung you headlong from the heights of heaven into the depths of hell. It is He who commands you, He who once stilled the sea and the wind and the storm ... (Your Catholic Voice Foundation, 2017).

Peminjaman otoritas ini juga dipreskripsikan oleh Katekismus Gereja Katholik, yang berbunyi demikian:

When the Church asks publicly and authoritatively in the name of Jesus Christ that a person or object be protected against the power of the Evil One and withdrawn from his dominion, it is called exorcism. Jesus performed exorcisms and from him the Church has received the power and office of exorcizing (Cathecism of Catholic Church, II.2. Bab 2. Art. 1, paragraf 1673). 
Gereja Katholik Roma juga mencantumkan Markus 1:25-26; 3:15; 6:7, 13; dan 16:17 sebagai referensi ayat landasan dari paragraf tersebut.

Tidak terlalu jelas apakah frasa "publicly and authoritatively in the name of Jesus Christ" pada katekismus tersebut berarti bahwa seseorang yang hendak mengusir setan harus mengucapkan nama "Yesus" atau frasa "dalam nama Yesus" secara verbal.

Namun, Bill Subritzky, dalam bukunya How to Cast Out Demons and Break Curses, menyatakan bahwa Roma 10:13 menjadi dasar mengapa penyebutan nama Yesus penting dalam pengusiran setan (Subritzky, 1991, p. 25). Lebih lanjut lagi, dalam metode pembebasan yang dia usulkan, korban kerasukan dianjurkan untuk menyebut nama Yesus. Dia juga memberikan anjuran mengenai doa yang harus diucapkan sebelum pembebasan korban kerasukan. Dalam doa tersebut, tertulis "In the name of Jesus Christ, Risen Saviour, I command every demonic power that has lived within me or oppressed me to leave me now in the name of Jesus Christ" (Subritzky, 1991, p. 29). Jelas sekali bahwa nama Yesus Kristus penting disebut.

Dari pengamatan sejauh ini, saya melihat adanya anggapan bahwa penggunaan nama Yesus dalam konteks ritual pengusiran setan, baik yang nampak pada doa maupun pada pernyataan-pernyataan hardikan, merupakan hal yang penting untuk dilakukan sebab itu adalah cara meminjam otoritas Kristus yang dianggap berkuasa melawan setan yang membelenggu korban. Namun, melalui penelusuran sejauh ini, tidak ada keharusan bagi seseorang untuk mengucapkan nama Yesus secara oral ketika proses pengusiran setan berlangsung. Yang sesungguhnya dibutuhkan, berdasarkan indikasi Alkitab, adalah iman kepada Yesus Kristus yang memberikan otoritas pengusiran setan itu sendiri.

\section{METODE}

Dari asumsi sementara tersebut saya melakukan penelusuran dan menuliskannya dalam artikel ini. Demi mencari argumentasi baik itu untuk membuktikan maupun untuk menolak apakah proses pengusiran setan harus disertai dengan penyebutan nama "Yesus" atau frasa "dalam/demi nama Yesus," saya melakukan survei biblis terhadap beberapa teks Perjanjian Baru yang berkaitan dengan praktik pengusiran setan. Metode yang digunakan dalam artikel ini adalah murni penelitian literatur (kepustakaan), baik itu dari teks-teks Alkitab maupun pada buku-buku dari para teolog biblika yang membahas ayat-ayat terkait. Ayat-ayat tersebut adalah Matius 7:22; 8:16; 9:32-34; 12:24-28; 16:17; Markus 1:34; 9:38; Lukas 9:49; Kisah Para Rasul 16:18; 19:13. Ayatayat tersebut adalah sumber-sumber paling utama dalam penelitian ini.

Kemudian, saya mengkategorikan teks-teks terkait pengusiran setan tersebut berdasarkan jenis teksnya. Saya memasukkannya dalam tiga kategori:

1. Teks-teks terkait pengusiran setan tanpa penggunaan nama Yesus.

2. Teks-teks dengan kemunculan frasa "demi nama Yesus" dalam narasi.

3. Teks-teks yang mengandung frasa "demi/dalam nama Yesus" secara oral dalam hardikan tokoh.

Sumber-sumber berikutnya adalah beberapa tulisan tafsiran mengenai teksteks tersebut. Untuk ayat-ayat di Matius, saya memakai beberapa judul tafsiran seperti Matthew (The New American Commentary 22) (Blomberg, 2001) dan Matthew 1-7 (Davies dan Allison, 2004). Untuk Markus, dua tulisan penting, yakni $A$ Critical and Exegetical Commentary on the Gospel According to St. Mark (Gould, 1922) dan Mark (New International Biblical 
Commentary) (Hurtado, 1989) layak ditelaah kendati pun berusia tua. Ada juga sumber baru seperti Mark 8-16: A New Translation with Introduction and Commentary (Marcus, 2009). Untuk ayat-ayat di Kisah Para Rasul, saya menggunakan Acts (The IVP New Testament Commentary) (Larkin, Briscoe, \& Robinson, 1995), Acts (Augsburg Commentary on the New Testament) (Krodel, 1986) dan The Acts of the Apostles (Peterson, 2009). Selain sumber-sumber di atas, ada pula sumber-sumber lainnya yang juga berupa tafsiran.

Saya juga dibantu oleh tiga tulisan penting yang menjelaskan konteks historis pengusiran setan di abad pertama. Ketiga tulisan itu adalah Acts (The New American Commentary 26) (Polhill, 2001), Acts: An Introduction and Commentary (Marshall, 1980), dan The Book of the Acts (Bruce, 1988).

Setelah melakukan penelusuran terhadap teks-teks tersebut serta melakukan penafsiran dengan bantuan beberapa sumber di atas, saya menentukan seberapa besar indikasi dalam masing-masing yang menyatakan bahwa seorang pengusir setan harus menyebutkan "dalam/demi nama Yesus" dalam proses pengusiran setan. Kemudian saya merangkumnya dalam sebuah tabel.

Melalui proses ini, saya hendak menjelaskan signifikansi penyebutan nama Yesus terhadap proses pengusiran, baik bagi pelaku maupun bagi setan yang membelenggu korban. Paling tidak, survei terhadap teks-teks Perjanjian Baru ini dapat menunjukkan diharuskan atau tidaknya penyebutan nama Yesus secara oral dalam proses pengusiran setan.

\section{HASIL DAN PEMBAHASAN}

\section{Teks-teks Terkait Pengusiran Tanpa Penggunaan Nama Yesus}

Sebenarnya ada beberapa teks terkait pengusiran setan yang tidak menggunakan penyebutan nama Yesus. Penting juga untuk memperhatikan ayat-ayat ini dan menarik kesimpulan darinya. Beberapa ayatayat dalam kategori ini tidak memberikan keterangan apa-apa yang mengarah pada kesimpulan bahwa seseorang diharuskan menyebut nama Yesus atau frasa "dalam nama Yesus" ketika mengusir setan. Matius 8:16, misalnya, hanya mengatakan bahwa

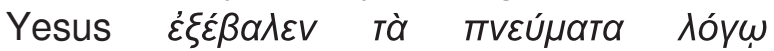
(mengusir roh-roh itu dengan satu kata). Terkait penggunaan $\lambda o ́ y \omega$, D. A. Carson menjelaskan bahwa Matius tidak dengan konsisten dalam menggunakan kata itu. Kadang kala dia mencatumkannya sebagai pelengkap aksi penyembuhan Yesus (ay. 3, 8), tetapi kadangkala tidak (ay. 15) (Carson, 1984, p. 204). Sulit untuk menyimpulkan bahwa "satu kata" itu adalah formula yang digunakan oleh Yesus.

Tidak jelas juga kata apa yang dimaksud. Yesus jelas tidak mungkin menyebut namanya sendiri atau mengucapkan "dalam nama Yesus". Karena itu, tidak ada indikasi apapun yang bisa didapatkan dari munculnya petunjuk $\lambda o ́ y \omega$ di teks ini kecuali fakta bahwa Yesus mengucapkan sesuatu. Apakah satu kata yang tidak diketahui ini di masa berikutnya menjadi formula yang diucapkan oleh murid-murid Yesus ketika mengusir setan, itu pun masih belum bisa disimpulkan demikian.

Teks lain yang tidak mengindikasikan penggunaan nama Yesus adalah kisah tuduhan musuh-musuh Kristus mengenai kuasa yang digunakan-Nya (Mat. 9:34; 12:24, 27-28). Orang-orang Farisi menuduhnya menggunakan "kuasa penghulu setan". Menurut Donald A. Hagner, mereka sedang terjebak dalam keadaan dilematis. Mereka tidak bisa menolak kuasa tindakan Yesus, tetapi juga tidak mau merelasikannya dengan kuasa Allah $\mathrm{YHWH}$ (Hagner, 2002, p. 342). Mereka mengambil solusi tengah, yaitu mengafirmasi kuasa tindakan Yesus tetapi mengkaitkannya dengan penghulu setan. Kesempatan untuk mengambil pilihan tersebut hanya mungkin ada bila Yesus tidak mengatakan sepatah 
kata pun mengenai nama-Nya atau nama YHWH. Akibatnya, kisah ini hanya bisa menunjukkan bahwa Yesus tidak menggunakan formula apa-apa, khususnya yang mengandung nama diri-Nya. Lebih-lebih ketika Yesus memberikan tekanan pada kuasa Roh Allah (Mat. 12:28) ketimbang pada kata-kata, kesimpulan yang bisa didapat hanyalah bahwa Yesus menggunakan kuasa Allah ketika mengusir setan.

Rujukan lain yang tidak berfokus pada kata-kata juga muncul pada Matius 17:19. Dalam perikop tersebut, ketika murid-muridNya tidak dapat mengusir setan, Yesus menuduh mereka kurang percaya. Dari tindakan Yesus, dapat disimpulkan bahwa iman merupakan hal yang niscaya diperlukan dalam pengusiran setan. Craig L. Blomberg menambahkan keterangan bahwa iman tersebut tidak bisa dilepaskan dari ketaatan dan pengharapan pada Kristus. Blomberg sangat beralasan, sebab Matius sangat menekankan iman kepada kuasa Kristus yang dinyatakan di dunia (Mat. 6:10). Karena itu, frasa "takkan ada yang mustahil bagimu" (Mat. 17:20) harus dibaca demikian: "Tidak ada tindakan, yang kepadamu Yesus sudah berikan otoritas, yang mustahil kamu lakukan," termasuk pengusiran setan (Blomberg, 2001, p. 268).

Selain beberapa hal di atas, ayat lain terkait dengan pengusiran setan adalah Markus 1:34. Bagian tersebut semakin tidak memberikan petunjuk apa-apa.

Apa yang sementara ini dapat disimpulkan dari penelusuran terhadap teksteks terkait pengusiran setan yang tidak menggunakan "nama Yesus" adalah bahwa pengusiran setan niscaya memerlukan kuasa dari Roh Allah sendiri (Mat. 9:27-28), iman akan otoritas Kristus yang menolong orang percaya dalam mengusir setan (Mat. 17:20), serta kemungkinan adanya kata-kata hardikan yang belum jelas juga apa bentuknya (Mat. 8:16).

\section{Teks-teks Dengan Kemunculan Frasa "Demi Nama Yesus" dalam Narasi}

Setidaknya ada tiga narasi yang di dalamnya muncul frasa "demi nama Yesus" yang dikatakan oleh penulis Injil. ${ }^{3}$ Yang pertama adalah nubuatan eskatologis mengenai orang-orang yang mengusir setan

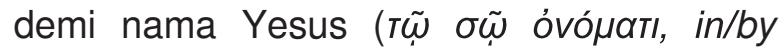
Your name [Mat. 7:22]). Yang kedua adalah mengenai preskripsi Yesus mengenai tandatanda yang akan menyertai dan menandai status murid-murid-Nya, yaitu mengusir

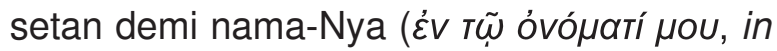
the name of $\mathrm{Me}$ [Mrk. 16:17]). ${ }^{4}$ Yang terakhir adalah narasi pararel tentang pengusiran setan yang dilakukan oleh orang-orang yang

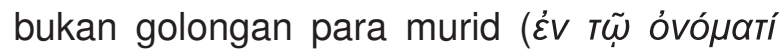
oou, in the name of You [Mrk 9:38; Luk. 9:49]).

Dari ketiga narasi tersebut, ada dua penggunaan gramatika yang berbeda. Yang pertama adalah frasa $\tau \tilde{\omega}$ $\sigma \tilde{\omega}$ óvó $\mu \alpha t ı$ seperti yang dituliskan oleh Matius (7:22). Bentuk datif lokatif (locatival dative) dari frasa tersebut juga memberikan arti "in union with you". Dengan kata lain, semantika dari bentuk gramatika ini terkait dengan kesatuan dan kebersamaan dengan Yesus (Osborn, 2010, p. 274).

Davies dan Allison (2004). memberikan 6 (enam) kemungkinan penafsiran mengenai frasa "in the name of You" dalam narasi Matius, yaitu:

1. Anggapan akan tindakan yang dilakukan in the power of His name atau by His authority.

2. Penggunaan nama Yesus untuk mengimpresi orang lain bahwa dia adalah Yesus yang akan datang kembali.

3. Klaim bahwa dia adalah seorang Kristen.

4. Formula pengusiran setan.

5. Pengakuan seorang mesias palsu, yang tidak mengindikasikan dirinya dengan pribadi Yesus.

6. Atau bisa berarti (1) dalam teks Matius 7:22 dan berarti (2)-(5) dalam teks Matius 24:5. 
Davies dan Allison memberikan kemungkinan akan adanya formula tertentu dengan mencantumkan kemungkinan penafsiran nomor (4). Namun, menurut Davies dan Allison penafsiran (6) lebih mungkin diterima. Menurut saya, bisa jadi mereka tidak mau berspekulasi dalam menafsirkan kemunculan frasa tersebut dalam Injil Matius. Akan tetapi, fakta bahwa Matius sendiri tidak secara konsisten memilih konteks di mana frasa itu dimunculkan membuat penafsiran 6 lebih solutif untuk diterima (Davies dan Alison, 2004).

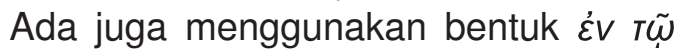
óvómatí (Mrk. 9:38; 16:17; Luk. 9:49). Berbeda dengan sebelumnya, terdapat preposisi $\varepsilon v$ sebelum frasa datif lokatif tersebut. Joel Marcus menganggap bahwa pola tersebut muncul dalam budaya kuno dan bisa berarti "in the power of" (lih. 11:9; 13:13; bdk. Mzm. 54:1; Kis. 4:7) atau "for the sake of' (9:37, 41) (Marcus, 2009). Karena itu, tidak ada kesimpulan yang didapat selain bahwa kuasa Yesus sedang dipinjam ketika pengusiran setan. Tidak ada indikasi bahwa nama itu disebutkan secara harafiah. Ini juga ditunjukkan dengan kesan ketidaksetujuan Marcus terhadap pembaca masa kini. Marcus mengatakan,

But in the present instance the reference is first and foremost to magical manipulation of the name in a literal sense: the would-be exorcist pronounces Jesus' name in order to bring his spiritual force to bear on demons (Marcus, 2009, p. 684).

Mungkin penjelasan paling mendalam

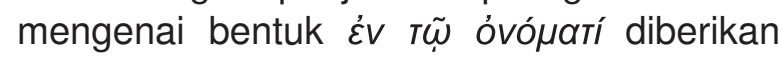
oleh Ezra Palmer Gould hampir seabad lalu. Menurutnya,

The prep. denotes the basis, the ground of the reception. This use of the word obvoua to denote the various things about a person recalled by his name, especially in

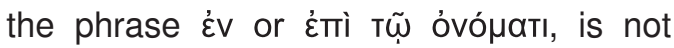
Greek, but Hebrew. The phrase indicates that a person is so connected with another, that he receives whatever consideration belongs to that other. The connection of thought, however, shows that, just as the personal consideration is excluded by this phrase, showing that the man is not received for himself, but because of Jesus; so it cannot be a mere outward connection with our Lord, but because the man's childlikeness makes him like Jesus, so that men are reminded of Jesus when they see him (Gould, 1992, p. 174).

Sebagai informasi, komentar Gould ditujukan tidak hanya pada frasa $\varepsilon^{\prime} v \quad r \tilde{\omega}$

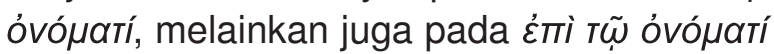
$\mu$ ou (atas nama-Mu) yang sebelumnya muncul pada kisah anak-anak yang datang kepada Yesus ("menyambut seorang anak seperti ini dalam nama-Ku," 9:37). Lalu, karena Gould menganggap bahwa relasi murid-murid dengan Allah mendasari penerimaan mereka terhadap anak-anak (9:37), maka adalah kongruen bila saya juga menganggap bahwa relasi dengan Allah juga mendasari kemampuan murid-murid untuk mengusir setan (9:38).

\section{Frasa "demi/dalam Nama" Selalu Mengenai Relasi Seseorang dengan Yesus}

Yang menarik, apa yang menyatukan ketiga lokasi frasa tersebut adalah kesamaan konteks dari ketiga narasinya. Peletakannya, oleh penulis Injil tentunya, memagari kemunculan frasa $\varepsilon^{\prime} v$ (atau $\dot{\varepsilon} \pi i$ ) $T \tilde{\omega}$ óvóparí dalam konteks identifikasi status seseorang: bahwa apakah orang yang disebutkan merupakan golongan pengikut Kristus atau tidak.

Matius 7:22, misalnya, mengatakan bahwa pengakuan orang yang sudah mengusir setan demi nama Yesus itu bukan dimaksudkan untuk meminta balas budi, melainkan sekadar mengungkapkan siapa diri mereka (Mounce, 1991). Implikasinya, ini juga mengenai hubungan antara mereka dengan Yesus. Hal ini juga disetujui oleh Robert H. Smith dengan mengatakan, 
To each of those inspired working in turn they attach the formula in your name. They claim that they are his own and have acted in his name and by his authority, and they seek his approval (Smith, 1989, p. 125$).{ }^{5}$

Kisah di Markus 9:38 tidak jauh dari itu. Perkataan Yohanes sangat menentukan konteks munculnya frasa "demi nama-Mu". Yohanes mempermasalahkan tindakan mereka yang mengusir setan demi nama Yesus, tetapi faktanya mereka selama ini tidak bersama-sama dengan para pengikut Yesus. Asumsi terbesar di benak Yohanes adalah bahwa seharusnya yang bisa mengusir setan demi nama Yesus adalah orang-orang yang selama ini menjadi murid Yesus, atau paling tidak mengikuti perjalanan Yesus. Dengan kata lain, Yohanes memahami bahwa pengusiran setan demi nama Yesus menandakan relasi pengusir setan tersebut dengan Yesus sendiri.

Sebagai dukungan terhadap asumsi saya tersebut, Larry Hurtado memberikan pendapat yang sama mengenai konteks penyebutan nama Yesus dalam perikop Markus 8:38. Menurutnya protes Yohanes di kisah itu menunjukkan bahwa hanya murid Yesus yang asli-lah yang boleh mengusir setan demi nama Yesus. Hurtado mengatakan, "the issue is not the practice of exorcism but whether a person who is not identified with the Twelve can still be a true follower of Jesus with the right to minister in his name" (Hurtado, 1989, p. 155).

Hurtado bahkan lebih lanjut menyimpulkan bahwa orang yang disebut Yohanes di sini menyebutkan nama Yesus secara oral ketika pengusiran setan. Dukungan bagi kesimpulannya dimunculkan dengan menyatakan bahwa ada contoh lain dari penggunaan "nama Yesus," yakni dalam Kisah Para Rasul 19:11. Namun, kisah itu "condemns the practice, implying that only genuine followers of Jesus can use his name effectually" (Hurtado, 1989, p. 154). Saya di sini tidak serta merta setuju dengan kesimpulan Hurtado, sebab hal itu hanya asumsi belaka. Hurtado tidak cukup memberikan bukti yang dapat menunjukkan bahwa orang yang disebut oleh Yohanes dalam catatan Markus benar-benar menyebut nama Yesus secara oral. Di luar dari pada itu, menyetujui pandangan Hurtado mengenai konteks identifikasi identitas sang pengusir setan tidak mengharuskan saya menyetujui kesimpulan Hurtado mengenai metode pengusiran setan yang diasumsikan dalam narasi Markus itu. ${ }^{6}$

Narasi di akhir Injil Markus (16:17) juga berada dalam konteks menjelaskan identitas orang-orang percaya. Bahkan Kristus sendiri yang berucap nubuat di sini. Yesus mengatakan bahwa orang percaya akan memiliki apa yang disebut oleh Adela Yarbro Collins dan Harold W. Attridge "miracle-list" (Collins dan Attridge, 2007, p. 811). Dengan adanya miracle-list tersebut, orang-orang melihat bahwa mereka adalah orang percaya.

Sampai di titik ini, yakni sejauh penelusuran terhadap teks-teks narasi pengusiran setan yang memunculkan frasa "demi nama Yesus," kesimpulan yang bisa didapat adalah bahwa tidak ada keharusan bagi orang percaya untuk mengucapkan kata "demi nama Yesus" pada waktu pengusiran setan. ${ }^{7}$ Apa yang terpenting adalah bahwa orang yang melakukan tindakan "demi/dalam nama Yesus" itu termasuk dalam lingkaran orang percaya.

\section{Teks-teks yang Mengandung Frasa "Demi/Dalam Nama Yesus" Secara Oral dalam Hardikan Tokoh}

Dua ayat terakhir yang sepertinya lebih memberikan titik terang adalah Kisah Para Rasul 16:18 dan 19:13. Narasi pertama (Kis. 16:16-18) terjadi di Filipi, persisnya ketika Paulus pergi ke tempat sembahyang. Setelah beberapa hari mendengar perempuan penenung itu berseru-seru padanya, Paulus akhirnya menghardik dengan mengatakan, "Demi nama Yesus Kristus aku menyuruh engkau keluar dari perempuan 
ini” (16:18).

Ayat ini sepertinya lebih terang dalam memberikan indikasi bahwa penyebutan nama Kristus memang penting, sebab Paulus sendiri melakukannya. Akan tetapi, mereka yang menyetujui bahwa ada hal yang normatif dari tulisan deskriptif ini pun tidak mengatakan bahwa penyebutan nama menjadi yang terpenting. William J. Larkin dan rekan-rekannya, misalnya, hanya menekankan pentingnya iman yang mengiringi perintah yang sederhana, yaitu "keluarlah!" Larkin dan rekan-rekannya berujar,

Christians confronting the forces of evil today can find guidance here ... Both Jesus and Paul dealt authoritatively with the demon-possessed using the simple command "Come out!" and the results were immediate (Lk 4:35; 8:29; 9:42; $11: 14) \quad \ldots$ Paul's authority and ours is christocentric and derived ... Exorcism must be approached today, then, with much care, humility and prayer. But there must also be bold confidence that Jesus is still bringing release to the captives (Lk 4:18) (Larkin, Briscoe, \& Robinson, 1995, s.v. 16:16).

Apa yang dapat diimplikasikan dari narasi itu adalah bahwa Paulus dengan sangat yakin bahwa otoritas tertinggi, termasuk dalam melawan kuasa roh jahat, ada pada Kristus.

Namun, pertanyaan berikutnya muncul. Bila yang terpenting adalah iman, mengapa Paulus menyebutnya secara oral? Apa pentingnya? Nampaknya memang ada alasan lain mengapa Paulus menyebut nama Yesus secara oral.

Menurut penjelasan Craig Keener, penggunaan nama Yesus oleh Paulus menghilangkan kemungkinan ambigu dari julukan yang dialamatkan oleh penenung tersebut, yaitu "Allah yang Mahatinggi" dan "pemilik jalan keselamatan" (16:18) (Keener, 2014, p. 2464). Lukas menganggapnya penting sehingga tak lupa menuliskan detail kejadiannya. Dengan menuliskan penye- butan Paulus terhadap nama Yesus, Lukas ingin pembacanya mengerti bahwa yang merupakan "Allah yang Mahatinggi" dan "pemilik jalan keselamatan" adalah Yesus Kristus, bukan yang lain. Paulus tidak memunculkan otoritas dari nama yang samarsamar seperti "Allah yang Mahatinggi," tetapi nama "Yesus" secara eksplisit (Wright, 2008, p. 64).

Pertimbangkan juga fakta bahwa konteks politeisme helenis di era itu membuat seseorang sulit menerima bahwa Yesus satu-satunya Tuhan. Mungkin bagi mereka Yesus adalah salah satu dari kumpulan tuhan dalam pantheon. Akibatnya memberitakan Kristus sebagai "tuhan" memiliki resiko bahwa Yesus hanya diterima sebagai daftar tuhan yang baru. Karena itu, untuk mengingatkan pada kuasa Yesus Kristus akan semua makhluk, termasuk roh jahat, Paulus menggunakan nama Yesus dalam pengusiran setan (Polhill, 2001, p. 351). Nama Yesus tidak hanya diberitakan, melainkan juga diproklamasikan sebagai bentuk penolakan terhadap roh lain.

Baik Lukas dan Paulus punya motif yang sama, yaitu bahwa semua orang harus mengetahui bahwa otoritas tertinggi ada pada Kristus, termasuk ketika mengusir setan. Paulus menyebutnya demi menunjukkan kepada wanita yang dirasuki, sedangkan Lukas mencatatnya demi memberitahukan pada pembacanya.

Lalu, tidak bisakah tindakan ini juga dianggap normatif dan dijadikan ritual wajib dalam pengusiran setan di zaman sekarang? Saya menganggap bahwa jika memang tujuan Paulus dan Lukas adalah agar pendengar atau pembacanya mengetahui bahwa otoritas tertinggi di alam semesta adalah Yesus, maka penyebutan nama Yesus dalam pengusiran setan di era ini juga diperlukan dengan alasan yang sama. Akan tetapi, tidak ada keharusan penyebutan nama Yesus bila intensi pengusir setan adalah demi memberi dampak pada setan yang merasuki. Tanpa penyebutan nama Yesus, setan apa pun, di 
zaman apa pun, mengetahui apakah seseorang melakukan ritual pengusiran setan dengan iman kepada Yesus Kristus atau tidak. Sampai di sinilah kesimpulan yang bisa ditarik dari kejadian di Filipi ini.

Kemudian, disputasi terhadap keharusan akan penyebutan nama Yesus akan lebih kuat bila didasarkan pada ayat selanjutnya, yaitu Kisah Para Rasul 19:13. Kali ini Paulus tiba di kota Efesus, sebuah kota dengan tingkat paganisme yang sangat tinggi. Di sana Paulus bertemu dengan beberapa tukang jampi Yahudi, yaitu anakanak Skewa. Mereka mencoba menyebut nama Tuhan Yesus atas mereka yang kerasukan. Lukas mengutip perkataan mereka ketika menghardik demikian katanya, "Aku menyumpahi kamu demi nama Yesus yang diberitakan oleh Paulus" (19:13). Akan tetapi roh jahat itu tidak pergi, melainkan menjawab, "Yesus aku kenal, dan Paulus aku ketahui, tetapi kamu, siapakah kamu?" (19:15). Roh jahat itu kemudian menyerang dan menggagahi anak-anak Skewa hingga telanjang dan luka-luka.

Nampaknya, pekerjaan Paulus membuat namanya makin tenar. Akibatnya, beberapa orang sepertinya melakukan observasi mengenai pribadi dan pekerjaan Paulus (Polhill, 2001). Ditambah dengan fakta bahwa di era itu Yesus cukup dikenal sebagai exorcist yang berhasil, orang-orang semakin percaya bahwa formula pengutipan nama Yesus akan menolong mereka melakukan mukjizat yang sama (Dunn dan Twelftree, 1980). Mereka kemudian menirunya demi keuntungan dan ketenaran diri mereka. Sayangnya, apa yang mereka lakukan tidak berbuah hasil yang sama dengan apa yang para rasul lakukan.

Yang menarik, sebenarnya penyebutan vulgar akan nama Allah Israel dengan bibir tidak biasa dilakukan sebelum era itu. Karena itu, pengusiran yang dilakukan oleh rasul-rasul di abad pertama menarik perhatian banyak orang, bahkan membuat mereka menirunya. Lucunya, ada data yang menceritakan bahwa ada juga dukun pengusir setan yang mencatat semua data tuhan yang bisa mereka sebutkan ketika mengusir setan. Seringkali mereka menyebutkan daftar panjang dari tuhan-tuhan tersebut ketika melakukan praktik pengusiran setan (Marshall, 1980).

Sebuah kisah mirip juga terjadi dan tercatat di sebuah papirus yang ditemukan. Diceritakan bahwa ada orang-orang yang meniru pengusiran setan dengan menyebut nama Yesus yang dilakukan oleh rasulrasul, tetapi sekaligus misinterpretasi terhadap profil Yesus. Papirus tersebut mencatat, "I adjure you by Jesus, the God of the Hebrews" (Bruce, 1988, p. 368). Sangat jelas bahwa praktik pengusiran setan itu menarik perhatian mereka yang bukan rasul, sekaligus membuat mereka menirunya. Sayangnya mereka tidak mempedulikan makna dari nama tersebut.

Bagi penyihir di zaman itu, nama Tuhan hanyalah sebagai media. Mereka tidak mengenal dan percaya pada Yesus, tetapi menggunakan nama-Nya untuk tujuan mereka, yaitu mengusir setan (Krodel, 1986). Dari apa yang akhirnya dilakukan oleh roh itu kepada mereka, Yesus yang sudah naik ke surga seakan-akan menyampaikan pada anak-anak Skewa bahwa Dia tidak ingin nama-Nya digunakan sebagai formula magis belaka. Yesus tidak akan membiarkan orang mereduksi makna dari penyebutan nama-Nya (Peterson, 2009). Prinsip teologis ini sangat konsisten dengan apa yang disampaikan Tuhan melalui kedua loh batu, "Jangan menyebut nama Tuhan, Allahmu, dengan sembarangan, sebab Tuhan akan memandang bersalah orang yang menyebut nama-Nya dengan sembarangan" (Kel. 20:7) (Peterson, 2009, p. 538).

Apa yang kembali penting untuk diingat adalah bahwa pengusiran setan, baik menggunakan nama Yesus atau tidak, harus didasarkan pada iman terhadap Yesus Kristus, Sang Penguasa alam semesta. Kuasa-Nyalah yang membuat roh-roh jahat takluk, bukan penyebutan nama-Nya. Sebagaimana Peterson sampaikan, 
Although they sought to emulate Paul by saying, "In the name of Jesus, whom Paul preaches, I command you to come out", they were unsuccessful. The implication is that the name of Jesus was effective to deliver and to heal only when used by those who genuinely called upon Jesus as Lord. These pretenders did not have the appropriate moral or spiritual integrity with which to engage the powers of evil (Peterson, 2009, p. 538).

Sampai di sini, berikut adalah rangkuman ayat-ayat yang sudah ditinjau di atas beserta dengan pendapat saya tentang seberapa kuat indikasi untuk secara normatif mengucapkan nama Yesus dalam proses pengusiran setan. Pada tabel, kolom "Ayat/Kisah" merujuk pada teks-teks yang diamati dalam penelitian ini. Kemudian, "Keterangan" berisi kata-kata kunci atau frasa yang dapat memberikan petunjuk penting yang bisa dijadikan argumentasi terhadap penarikan kesimpulan apakah ada indikasi bahwa mengusir setan harus disertai dengan penyebutan "dalam nama Yesus" secara oral. Sedangkan "Indikasi Normatif" berisi tentang kesimpulan yang saya ambil setelah meneliti teks. Indikasi dikategorikan menjadi 3 (tiga), yakni tidak ada indikasi, ada indikasi lemah, dan ada indikasi kuat.

Tabel 1

Ragam Teks Terkait Pengusiran setan

\begin{tabular}{|l|l|l|}
\hline Ayat/Kisah & Keterangan & $\begin{array}{l}\text { Indikasi } \\
\text { Normatif }\end{array}$ \\
\hline \multicolumn{3}{|c|}{ Tanpa Penggunaan Nama Yesus } \\
\hline Mat. 8:16 & $\begin{array}{l}\text { Ada frasa } \\
\text { "dengan satu } \\
\text { kata" }\end{array}$ & Lemah \\
\hline Mat. 9:32-34 & (tidak ada) & $\begin{array}{l}\text { Tidak } \\
\text { ada }\end{array}$ \\
\hline Mat. 12:24-28 & (tidak ada) & $\begin{array}{l}\text { Tidak } \\
\text { ada }\end{array}$ \\
\hline Mat. 17:14-21 & $\begin{array}{l}\text { Ada frasa } \\
\text { "kamu kurang } \\
\text { percaya" }\end{array}$ & $\begin{array}{l}\text { Tidak } \\
\text { ada }\end{array}$ \\
\hline
\end{tabular}

Bersambung ...
Lanjutan tabel 1

\begin{tabular}{|c|c|c|}
\hline Mrk. 1:34 & (tidak ada) & $\begin{array}{l}\text { Tidak } \\
\text { ada }\end{array}$ \\
\hline \multicolumn{3}{|c|}{ Narasi Pengusiran Demi Nama Yesus } \\
\hline Mat. $7: 22$ & 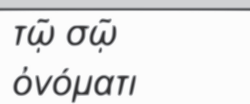 & $\begin{array}{l}\text { Tidak } \\
\text { ada }\end{array}$ \\
\hline Mrk. 16:17 & 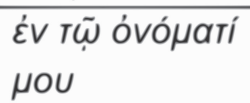 & $\begin{array}{l}\text { Tidak } \\
\text { ada }\end{array}$ \\
\hline $\begin{array}{l}\text { Mrk 9:38; Luk. } \\
\text { 9:49 }\end{array}$ & 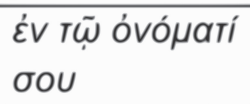 & $\begin{array}{l}\text { Tidak } \\
\text { ada }\end{array}$ \\
\hline \multicolumn{3}{|c|}{ "Demi Nama Yesus" Muncul Secara Oral } \\
\hline Kis. 16:18 & $\begin{array}{l}\text { Paulus } \\
\text { menyebut } \\
\text { "demi nama } \\
\text { Yesus" }\end{array}$ & Lemah \\
\hline Kis. 19:13 & $\begin{array}{l}\text { Menyebut } \\
\text { "demi nama } \\
\text { Yesus," tapi } \\
\text { gagal } \\
\text { mengusir } \\
\text { setan }\end{array}$ & Tidak ada \\
\hline
\end{tabular}

\section{KESIMPULAN}

Telah dijelaskan di atas bahwa teksteks terkait pengusiran setan yang tidak memiliki indikasi penggunaan nama Yesus secara oral (Mat. 8:16; 9:34; 12:24, 27-28; 17:19; Mrk. 1:34) hampir tidak menunjukkan adanya keharusan untuk menyebut nama Yesus ketika mengusir setan. Hal yang dapat disimpulkan dari teks-teks semacam itu adalah bahwa pengusiran setan memerlukan kuasa dari Allah (Mat. 9:27-28) dan berisi kata-kata hardikan yang belum jelas juga apa bentuknya (Mat. 8:16).

Dalam teks-teks lain, ada indikasi bahwa seseorang mengusir setan demi nama Yesus (Mat. 7:22; Mrk. 16:17; Mrk 9:38; Luk. 9:49). Hanya saja teks-teks itu tidak sedang berbicara tentang penyebutan nama Yesus yang secara eksplisit keluar dari bibir. Justru prinsip yang didapat dari beberapa narasi yang digambarkan ayat-ayat itu adalah bahwa pengusiran setan harus dilakukan oleh orang yang punya relasi dengan Yesus Kristus. Hal ini masih koheren dengan kesimpulan yang didapat dari penelusuran 
terhadap ayat-ayat sebelumnya yang menunjukkan bahwa kuasa Allah diperlukan dalam pengusiran setan. Dengan memiliki relasi dengan Yesus Kristus, pengusir bisa melakukan ritual itu bukan karena kemampuannya sendiri, melainkan kuasa Yesus yang telah diberikan padanya.

Dua ayat terakhir lebih jelas lagi berbicara tentang orang-orang yang menyebut nama Yesus secara oral. Di Filipi (Kis. 16:18) Paulus benar-benar menggunakan nama Yesus dalam mengusir setan. Hanya saja itu dilakukannya sebagai bentuk iman akan kuasa Yesus melawan roh jahat. Hal lain, penyebutan nama oleh Paulus sangat solutif dalam mengantitesis pemikiran paganis pada waktu itu. Dengan menyebutnya, Paulus memberitahukan bahwa otoritas tertinggi atas segala makhluk ada pada Kristus. Kristus, dalam artikulasi F. C. Conybeare, memiliki misi di dunia, yaitu

... to rid mankind of these pests; to dethrone Satan, and overcome disease and death. When this triumph over the demons is effected, the kingdom of God will be established (Conybeare, 1896, p. 589).

Dalam Kisah Para Rasul 19:13, lebih jelas lagi, penggunaan nama Yesus dalam mengusir setan tidak berdampak apa-apa

\section{DAFTAR RUJUKAN}

Balack, D. A. (2008). Perspectives on the Ending of Mark. Nashville: $\mathrm{B} \& \mathrm{H}$.

Blomberg, C. (2001). Matthew. The New American Commentary 22. Nashville: Broadman \& Holman.

Boring, M. E. (2006). Mark: A Commentary. Louisville: John Knox.

Bruce, F. F. (1988). The Book of the Acts. The New International Commentary on the New Testament. Grand Rapids: Eerdmans.

Carson, D. A. (1984). "Matthew." In Frank E. Gaebelein (Ed.), The Expositor's Bible Commentary. Vol. 8 (Matthew, Mark, bila si pengucapnya bukan pengikut Kristus. Apa yang terpenting adalah iman kepada Yesus, bukan penyebutan nama-Nya secara oral. Lagipula, menyebutkan nama Yesus sembarangan ketika mengusir setan dan dalam posisi tidak beriman membuat mereka dihina dan digagahi oleh roh jahat.

Allah memberikan kuasa itu pada umat-Nya. Yang harus dilakukan umat-Nya bukanlah mengucapkan formula-formula magis tertentu. Umat-Nya yang ingin mengusir setan harus sadar benar akan siapa dirinya dihadapan Tuhan. Dia harus sadar bahwa dia sedang memiliki relasi dengan Yesus Kristus. Dia harus tahu bahwa kuasa mengusir setan diberikan padanya oleh Kristus.

Oleh karena itu tindakan pengusiran setan harus benar-benar didasarkan pada kuasa Yesus dan relasi pengusir setan dengan Yesus, bukan penyebutan kalimatkalimat magis (lih. Kis. 19:13). Bahwa kemudian ada orang-orang yang menyebutkannya, hal itu tidak menjadi masalah. Penyebutan nama oleh rasul-rasul di era awal adalah bentuk meyakinkan diri dan orang lain bahwa Yesuslah pemilik otoritas tertinggi (lih. Kis. 16:18). Karena itu sah-sah saja bila di era ini ada orang-orang yang menyebutkan nama Yesus demi memproklamasikan pada orang lain bahwa Yesuslah pemilik otoritas tertinggi.

Luke). Grand Rapids: Zondervan.

Collins, A. Y. \& Attridge, H. W. (2007). A Commentary on the Gospel of Mark. Hermeneia. Minneapolis: Fortress.

Conybeare, F. C. (1896). The Demonology of the New Testament I. The Jewish Quarterly Review, 8(4), 576-608.

Davies, W. D. \& Allison, D. C. (2004). A Critical and Exegetical Commentary on the Gospel According to Saint Matthew. London: T\&T Clark.

Dunn, J. D. G. \& Twelftree, G. H. (1980). Demon-Possesion and Exorcism in the New Testament. Churchman, 94(3), 210-225. 
Ferguson, S. B. (1999). Let's Study Mark. Edinburgh: Banner of Truth Trust.

Gould, E. P. (1922). A Critical and Exegetical Commentary on the Gospel According to St. Mark. New York: C. Scribner's Sons.

Hagner, D. A. (2002). Matthew 1-13. Word Biblical Commentary 33a. Dallas: Word.

Hurtado, L. W. (1989). Mark. New International Biblical Commentary. Peabody: Hendrickson.

Keener, C. S. (1993). The IVP Bible Background Commentary: New Testament. Illinois: InterVarsity.

(2014). Acts: An Exegetical Commentary. Vol. 3. Grand Rapids: Baker Academic.

Kernaghan, R. J. (2007). Mark. The IVP New Testament Commentaries Series. Downers Grove: InterVarsity.

Krodel, G. A. (1986). Acts. Augsburg Commentary on the New Testament. Minneapolis: Augsburg.

Larkin, W. J., Briscoe, D. S. \& Robinson, H. W. (1995). Acts. The IVP New Testament Commentary. Downers: InterVarsity.

May, G. (2014). "10 Modern Day Exorcism." Listverse.com. Retrieved from http://listverse.com/2013/ 08/14/10modern-day-exorcisms/

Marcus, J. (2009). Mark 8-16: A New Translation with Introduction and Commentary. New Haven: Yale University Press.

Marshall, I. H. (1980). Acts: An Introduction and Commentary. Tyndale New Testament Commentaries 5. Nottingham: Inter-Varsity.

Mounce, R. H. (1985). Matthew. New International Biblical Commentary.

\section{CATATAN AKHIR}

1. Proses ritual pengusiran setan terhadap Michel didokumentasikan dalam rekaman audio yang termuat dan dapat diunduh di laman AllThat/sInteresting.com (Paoletti, 2020).
Peabody: Hendrickson.

Ney-Hellmuth, P. (2014). Der Fall Anneliese Michel [The Case of Anneliese Michel]. Würzburg: Königshausen \& Neumann.

Paoletti, G. (2020). Anneliese Michel And The Shocking Images From The Exorcism Of The Real Emily Rose. AllThatlsInteresting.com. Retrieved from https://allthatsinteresting.com/ anneliese-michel-exorcism.

Peterson, D. G. (2009). The Acts of the Apostles. The Pillar New Testament Commentary. Grand Rapids: Eerdmans.

Polhill, J. B. (2001). Acts. The New American Commentary 26. Nashville: Broadman \& Holman.

Schweizer, E. (1970). The Good News According to Mark. Donald H. Madvig (Terj.). Atlanta: John Knox.

Sitompul, A. A. (2009). Sinopsis Tiga Injil. Jakarta: LAI.

Smith, R. H. (1989). Matthew. Augsburg Commentary on the New Testament. Minneapolis: Augsburg.

Subritzky, B. (1991). How to Cast Demons and Break Curses. Blockhouse Bay: Dove Ministries.

Swete, H. B. (1977). Commentary on Mark. Grand Rapids: Kregel.

Wolff, U. (2006). Der Teufel ist in mir [The Devil Is in Me]. Munich: Heyne.

Wright, T. (2008). Acts for Everyone Part 2: Chapters 13-28. London: Society for Promoting Christian Knowledge.

Your Catholic Voice Foundation. (2017). Rite of Exorcism. Catholic.org. Retrieved from http://www.catholic.org/prayers/ prayer.php? $p=683$

2. Tidak jelas apakah Litany of the Saints dilakukan di gereja atau di lokasi pengusiran setan. Panduan doa tersebut hanya menunjukkan dua tahap besar tersebut, yaitu ritual permohonan kelayakan tugas dan ritual 
pengusiran setan.

3. Saya tidak membicarakan narasi yang di dalamnya pelaku mengucapkan "demi nama Yesus." Saya memaksudkan tindakan yang menggunakan frasa "demi nama Yesus" dalam narasi tersebut. Teks terkait penggunaan frasa "demi nama Yesus" yang diujarkan langsung oleh tokoh dalam narasi Alkitab akan dibahas di bagian berikutnya.

4. Sebenarnya fakta bahwa dipermasalahkannya ayat ini membuka kemungkinan bagi pembaca untuk meragukan apa yang disampaikan di akhir Injil Markus, termasuk preskripsi akan kuasa pengusiran setan. Bermasalahnya ayat itu juga ditunjukkan oleh beberapa sarjana biblika. Mereka menganggap bahwa bagian akhir, termasuk ayat 17, merupakan bagian yang hilang atau tidak diintensikan Markus untuk tertulis. Untuk diskusi lebih lanjut, lihat Ferguson, 1999; Swete, 1977; Balack, 2008; Elliot, bab. 2 dalam Black, 2008; Croy, 2003; Schweizer, 1970; Boring, 2006; Kernaghan, 2007; Keener, 1993; Sitompul, 2009. Akan tetapi, penolakan terhadap eksistensi ayat ini tidak memberikan kelonggaran apa-apa bagi orang-orang yang tidak setuju bahwa penyebutan nama Yesus diharuskan. Bahwa ayat tersebut bukan merupakan firman Tuhan, tetap saja mereka harus meneruskan penelitian untuk menjawab ayat-ayat serupa yang juga mengindikasikan penggunaan nama Yesus, setidaknya pada
Matius 7:22, Markus 3:38, dan Lukas 9:49.

5. Lebih lagi, Davies dan Allison menunjukkan konteks mengenai identifikasi status ini dengan cara menganggap sejajar dua bagian perikop tersebut dan menamainya the false prophets' deeds (7:16-20) dan the false prophets' words (7:21-23) (Davies dan Allison, 2004, p. 702).

6. Sebenarnya pandangan saya menimbulkan pertanyaan berikutnya. Dari mana Yohanes tahu bahwa orang yang ditunjuknya mengusir setan demi nama Yesus tanpa dia menyebutkan nama Yesus secara oral? Adakah cara lain untuk Yohanes mengidentifikasi niat atau pengakuan orang tersebut selain dari menyebutkan nama Yesus? Mungkin pertanyaan itulah yang memaksa Hurtado menyimpulkan bahwa orang tersebut mengusir setan dengan menggunakan nama Yesus sebagai ritual magis yang diucapkan secara oral. Akan tetapi, kalau pun pengusir setan itu menyebut nama Yesus secara oral, tidak ada kesan normatif dari Alkitab mengenai cara penggunaan nama Yesus yang demikian. Jadi adalah lebih baik kalau pembaca tetap mengikuti fokus narasi Markus 9:38, yaitu bahwa mereka yang mengusir setan demi nama Yesus adalah mereka yang sungguh-sungguh punya relasi dengan Kristus.

7. Pertanyaan yang sama pastinya juga muncul; bandingkan endnote sebelumnya. 